\title{
A UTILIZAÇÃO DE JOGOS DIGITAIS EDUCACIONAIS NA EDUCAÇÃO DE JOVENS E ADULTOS
}

\author{
THE USE OF DIGITAL EDUCATIONAL GAMES IN THE YOUTH AND ADULT \\ EDUCATION
}

\author{
Regina Claudia Pinheiro \\ Universidade Estadual do Ceará, Brasil \\ rclaudiap@yahoo.com.br \\ José Rogério de Oliveira \\ Universidade Estadual do Ceará, Brasil \\ rogerio_leonardo@hotmail.com
}

RESUMO: Os jogos educacionais digitais têm sido importantes ferramentas para a aprendizagem de diversos conteúdos. No entanto, na Educação de Jovens e Adultos (EJA), modalidade carente de material didático, esses recursos não têm sido muito utilizados, pois são escassos os jogos educacionais criados para este público. Acreditamos que uma das razões para esta carência seja o fato de se pensar que esses recursos são mais atrativos para crianças. Considerando o exposto, para este artigo, construímos um jogo educacional digital, a fim de explorar o seu potencial na EJA, com vistas a investigar se este contribui para a aprendizagem, por meio de práticas de letramentos. Como contribuição teórica, este artigo baseia-se, principalmente, em: Prensky (2001), Savi e Ulbricht (2008) e Pinheiro, Lima e Araújo (2020), sobre os benefícios dos jogos digitais educacionais para a aprendizagem; Freire (2018; 1987), sobre a conscientização do indivíduo e a aprendizagem contextualizada; Soares (2004), Kleiman (2007), Catelli Jr. (2014) e Pinheiro (2018) sobre letramentos. Dessa forma, após o desenvolvimento do jogo digital Xote da Preservação, que aborda questões ambientais, este foi aplicado em uma turma de jovens e adultos e buscamos, a partir da observação desta prática e de entrevistas, analisar suas considerações a respeito da atividade proposta. Como resultados, verificamos que o objeto desta investigação demonstrou grande potencial para alfabetização e conscientização dos alunos e, apesar de esta pesquisa identificar que as práticas auxiliadas pelas tecnologias não são recorrentes com o público-participante, o jogo despertou o interesse de todos os envolvidos, que se mostraram satisfeitos em jogá-lo.

PALAVRAS-CHAVE: Jogos digitais educacionais. Educação de jovens e adultos. Tecnologias digitais.

ABSTRACT: Digital educational games have been important tools for the learning of different contents, however, in the Youth and Adult Education (EJA), a modality lacking didactic material, these resources have not been widely used, as educational games created for this audience are scarce. It is believed that this lack of usage is due to the fact that these resources are thought to be more attractive to children. Considering the above, for this article, a digital educational game was created in order to explore its potential in EJA and to investigate if it contributes to learning through literacy practices. As a theoretical contribution, this article is based mainly on: Prensky (2001), Savi and Ulbricht 
(2008) and Pinheiro, Lima e Araújo (2020) on the benefits of educational digital games for learning; Freire (2018; 1987), on the individual's awareness and contextualized learning; Soares (2004), Kleiman (2007), Catelli Jr. (2014) and Pinheiro (2018) on literacies. Therefore, after the development of the digital game Xote da Preservação, which addresses environmental issues, it was applied in a class of young adults and adults and, through the observation of this practice and interviews, their considerations regarding the proposed activity were analyzed. As a result, it was found that the object of this research showed great potential for literacy and students' awareness and, although this study identifies that the practices aided by technologies are not recurrent with the participating public, the game stimulated the interest of all those involved, who were glad to play it.

KEYWORDS: Digital educational games. Youth and Adult Education. Digital Technologies.

\section{Introdução}

Com a constante evolução das tecnologias digitais, surgiram novos meios de se relacionar, interagir e estar no mundo. Esses recursos estão a nosso serviço, a fim de agilizar e facilitar nossas vidas em diversas atividades, tais como pedir um transporte ou comida e fazer operações em caixas eletrônicos, ou seja, a maioria de nossas práticas sociais, atualmente, passa por um processo tecnológico. Sendo assim, é difícil negar a tecnologia como parte usual de nossas vidas.

As tecnologias digitais estão também presentes na escola e, muitas vezes, assumem o papel de recurso didático-pedagógico, pois muitos educadores as utilizam como uma prática inovadora que desperta e instiga os alunos no processo de desenvolvimento da aprendizagem. Dessa forma, a educação se rendeu às tecnologias, pois são notáveis os esforços de sua inserção na prática, tais como a utilização de lousas digitais e de laboratórios de informática, além do uso desses recursos na educação a distância.

Essas constatações são divulgadas em pesquisas científicas ou observadas nas práticas escolares. No entanto, quando falamos em Educação de Jovens e Adultos, o desafio torna-se maior, pois esse público, muitas vezes, não cresceu com acesso às tecnologias. Assim, acreditamos que uma iniciativa menos rígida e não avaliativa, apresentada de maneira lúdica, poderá trazer resultados positivos. Pensando nisso, consideramos que os jogos digitais educacionais, ferramentas de caráter lúdico e desafiador, direcionados aos fundamentos pedagógicos, poderiam facilitar a aprendizagem desse público.

Nesta perspectiva, neste trabalho, objetivamos construir um jogo digital educacional e investigar seu potencial no processo de aprendizagem de jovens e adultos, por meio de das práticas de letramentos. Para tanto, estruturamos este trabalho em três seções, além desta introdução e das considerações finais. Na primeira seção, apresentamos um estudo bibliográfico acerca da Educação de Jovens e Adultos e dos jogos digitais educacionais, com tópicos relacionados à EJA como modalidade de ensino, à alfabetização e aos letramentos e, posteriormente, aos jogos digitais educacionais. $\mathrm{Na}$ segunda parte, descrevemos os procedimentos metodológicos que conduziram a produção deste trabalho. Por fim, apresentamos os resultados desta investigação, discutidos e analisados à luz da teoria. 


\section{Referencial teórico}

Nesta seção, abordamos a modalidade de Educação de Jovens e Adultos e os processos de alfabetização e letramentos desse público. Destacamos, ainda, estudos acerca dos jogos digitais educacionais.

\subsection{Alfabetização e letramentos na modalidade Educação de Jovens e Adultos}

A Educação de Jovens e Adultos (EJA) é uma modalidade de ensino voltada às pessoas que não concluíram a educação básica no período regular e que buscam a retomada dos estudos. A partir dos 15 anos de idade, caso não esteja no ano escolar adequado, o aluno pode optar por essa modalidade na etapa de Ensino Fundamental e, a partir de 18 anos, no Ensino Médio. A modalidade é uma forma de educação estipulada pela Lei de Diretrizes e Bases da Educação (LDB), n 9394/96, que contempla tanto a Educação Básica, quanto o Ensino Superior. Nesta lei, o Art. 37 assegura que "a educação de jovens e adultos será destinada àqueles que não tiveram acesso ou continuidade de estudos no ensino fundamental e médio na idade própria" (BRASIL, 1996, p. 30).

Dessa forma, mais que uma oportunidade, a Educação de Jovens e Adultos é um direito assegurado por lei, com condições apropriadas de ensino, respeitando as características e o modo de vida dos educandos (BRASIL, 1996). O chamamento para ingresso na modalidade é incentivado pelos órgãos responsáveis, com vista a alcançar o máximo de alunos possível, porém, quando não há a oferta de ensino, a iniciativa de ingresso nessa modalidade deve partir do próprio aluno, pois a oferta das aulas é um dever do Estado, assim como em toda a Educação Básica, como garante a LDB (BRASIL, 1996). No entanto, boa parte da população não tem esse conhecimento quando falamos em Educação de Jovens e Adultos. Essa falta de instrução e informação faz com que as pessoas fiquem à espera da oferta.

Embora a crescente procura por educação tenha avançado, há uma parcela significativa de pessoas que não é favorecida por ela e encontra-se com baixo ou nenhum grau de escolarização. O número de analfabetos no Brasil acima de 15 anos ainda é grande, pois gira em torno de 11,5 milhões, segundo dados do Instituto Brasileiro de Geografia e Estatística, de 2017 (IBGE, 2018). O Plano Nacional de Educação (20142024) tem como meta reduzir a taxa de analfabetismo para 6,5\% até 2015 (BRASIL, 2014), no entanto, constatamos que esta ainda não foi alcançada no Brasil e está distante de ser atingida até o fim do referido plano. Nesse sentido, constamos que ainda há muito a se fazer em termos de Educação de Jovens e Adultos e acreditamos que, muitas vezes, os alunos da EJA se evadem porque as aulas não são atrativas e estes trabalham o dia todo e vão para escola já cansados.

Muitos alunos que chegam à EJA têm a expectativa de aprender a ler e a escrever, por isso, a alfabetização e os letramentos sempre serão temas em discussão nos estudos, pesquisas e políticas educacionais, principalmente, por estarmos cercados de códigos que precisamos codificar, decodificar e utilizar a todo momento. Sem o domínio destes, colocamo-nos em uma condição de exclusão social, pois conhecê-los é uma necessidade, já que a sociedade exige dominá-los com propriedade para uso em diversas práticas sociais. Nessa perspectiva, o ensino da leitura e da escrita na EJA deve se pautar em atividades de uso real da escrita para os estudantes sentirem que aprender a ler e a 
escrever não é uma atividade mecânica e para ampliarem seus conhecimentos através do código escrito.

Paulo Freire, patrono da educação brasileira, via, na educação, uma prática que mantém a dominação dos opressores sobre os oprimidos. Para ele, há uma intencionalidade política que a torna não neutra, pois, a partir dela, o indivíduo é capaz de transformar o mundo e a condição de si mesmo, sendo a educação um ato político, pois diz respeito à vida social. O autor ainda tece uma crítica à educação bancária, até então predominante, aquela na qual o educador "deposita", nos educandos, conhecimentos e valores dissociados da realidade (FREIRE, 1987). Ele então propõe um método de alfabetização que caminharia lado a lado com os problemas sociais vigentes, que, ao mesmo tempo em que tiraria o indivíduo da condição de analfabeto, o levaria à libertação da opressão.

A proposta de Paulo Freire foi justamente trabalhar com as narrativas de vida dos seus educandos e trazer significado a elas, tornando-as objetos de estudos e conscientização. Esta última, a qual Freire se refere, diz respeito à tomada de consciência que o indivíduo tem a partir de um fenômeno, porém, ainda não é a conscientização, pois esta só é adquirida quando se tem uma visão crítica do fenômeno a qual se tomou consciência, portanto, uma incide sobre a outra (FREIRE, 2018). A comunhão que Paulo Freire apresenta, em sua obra Pedagogia do Oprimido (1987), propõe o diálogo entre o educador e educando sobre o mundo que o cerca, pois, muito antes de codificar e decodificar palavras, fazemos uma constante leitura das coisas que nos cercam, como os signos, símbolos, objetos e, principalmente, realizamos uma leitura da vida, do mundo.

É preciso conhecer os alunos por meio de sua história, pois, sabendo o que eles viveram e aprenderam, o educador poderá compreender sua realidade. Assim, é possível conhecer seus saberes prévios e suas dificuldades para ter mais liberdade e planejar melhor as atividades, pois, como afirma Kleiman (2007, p. 6), "[...] uma grande vantagem do enfoque socialmente contextualizado é a autonomia que ele ganha no planejamento das unidades de ensino e na escolha de materiais didáticos". Dessa forma, o educador relaciona os saberes curriculares com os saberes construídos no meio pessoal e social do educando, reconhecendo como muito válido aquilo que ele sabe.

Além dos conhecimentos que o educando traz, as situações práticas em que ele utilizará esse conhecimento levarão a práticas de letramentos, muito utilizado nos dias atuais para preparar o educando para reais situações nas quais este aplicará a leitura e a escrita. Catelli Jr. (2014) afirma que, em pleno século XXI, alfabetizar não é o suficiente, que o letramento de jovens e adultos precisa de avanços significativos, para que estes sejam capazes de exercer práticas de leitura e escrita na sociedade atual. Sobre essa questão, Soares $(2004$, p. 14) ressalta que não devemos dissociar alfabetização e letramento, pois,

a entrada da criança (e também do adulto analfabeto) no mundo da escrita ocorre simultaneamente por esses dois processos: pela aquisição do sistema convencional de escrita - a alfabetização - e pelo desenvolvimento de habilidades de uso desse sistema em atividades de leitura e escrita, nas práticas sociais que envolvem a língua escrita - o letramento.

Atualmente, os dois processos não são independentes, são simultâneos, pois a alfabetização se desenvolve em um contexto social no qual os indivíduos exercem práticas com a escrita e outros signos que fazem significar. Dessa forma, os educadores 
devem propor práticas sociais que envolvam a escrita, a oralidade e elementos visuais para que o aluno adquira o domínio dos códigos inseridos nas práticas de letramentos. Pensando sobre as práticas de leitura e escrita na atualidade, podemos afirmar que estas acompanharam a evolução das tecnologias digitais de informação e comunicação (TDICs), pois, comumente, vemos indivíduos analfabetos utilizando aparelhos tecnológicos, tais como smartphone, com uma certa desenvoltura, ou seja, exercendo práticas de letramentos em ambientes digitais. Sendo assim, consideramos que a ampliação dos letramentos de alunos da EJA com o uso das tecnologias pode ser uma alternativa eficiente. Dentre esses usos, consideramos que os jogos digitais, por serem atrativos para todas as idades, podem contribuir para esse processo.

\subsection{Jogos digitais educacionais}

A maneira como nos relacionamos, nos comunicamos e vivemos mudou, sendo a tecnologia de informação e comunicação uma das principais responsáveis por isso. Esses artefatos foram responsáveis por novas práticas sociais com a escrita, até mesmo por indivíduos que não conhecem este código, mas usam estratégias para sua decifração. Atualmente, acessar redes sociais, sites de notícias, mensagens eletrônicas, receitas e blogs é muito frequente nas sociedades. Essas atividades permitem que os cidadãos se mantenham conectados diariamente e estejam exercendo práticas de letramentos. No entanto, segundo Pinheiro (2018, p. 607), "no Brasil, o acesso da população às tecnologias digitais é inversamente proporcional ao desenvolvimento educacional da população", pois este é um dos países que mais acessou a internet e as redes sociais e estava em $59^{\circ}$ colocado em leitura na avaliação do PISA no ano de 2015.

Para além do uso da tecnologia, surge o desafio de utilizar o computador de forma mais dinâmica, uma vez que esta ferramenta dispõe de recursos que não se esgotam facilmente. Dessa forma, cabe ao professor um uso mais eficiente e planejado do computador, porém, muitas vezes, falta formação direcionada a essas ferramentas. Como alternativa, consideramos os jogos digitais ferramentas importantes para uso pedagógico, pois surgem como recurso para atender necessidades e romper barreiras existentes, permitindo novas emoções, principalmente, entre o público da modalidade EJA. Sendo assim, os jogos trazem consigo o desafio de tornar os alunos ativos em sua própria aprendizagem, pois sua dinâmica pode propiciar isso ao jogador. Sobre esse aspecto, Paula (2015, p. 60) afirma que

os jogos, por exemplo, posicionam seus jogadores no centro das ações, estimulando o protagonismo nos estudantes. Da mesma maneira, esses artefatos podem permitir que os educandos/jogadores aprendam através de seus próprios erros, já que, na maioria das vezes, seus fruidores podem repetir suas jogadas anteriores em caso de falhas, buscando corrigi-las.

O autor acredita que, com o jogo, o aluno tem autonomia de desenvolver a atividade no seu próprio tempo, de acordo com suas necessidades. As tentativas falhas podem servir de aprendizado, uma vez que muitos jogos contêm feedbacks instrutivos, que são as respostas da ação do jogador, para que o próprio aluno perceba seu erro e aprenda com ele, desenvolvendo, assim, o conhecimento. Prensky (2001, p. 1) também ressalta que a atratividade dos jogos envolve o jogador, impelindo-o a agir. Para ele, o 
envolvimento gerado pela ação do usuário e o feedback fazem o jogador aprender. Esses dois elementos também são responsáveis pela interação e socialização entre usuários desses recursos.

Para o uso de jogos digitais educacionais, é preciso levar em consideração a ludicidade, englobando as habilidades a serem desenvolvidas nos alunos e a relação com sua realidade, sem perder o caráter lúdico que os jogos trazem em sua essência. Essa ludicidade pode ser possibilitada, dentre outros aspectos, pelos elementos gráficos e sonoros do jogo. Sendo assim, as modalidades escrita, oral e visual, congregadas harmoniosamente nos jogos educativos digitais, podem atrair os jogadores, engajando-os para as ações do jogo e envolvendo-os no processo de aprendizagem. No entanto, muitas vezes, a escola está tão preocupada em ensinar a escrita que desconsidera essas outras modalidades tão presentes na sociedade e cada vez mais exigidas quando lidamos com tecnologias digitais. Sobre essa questão, Buzato (2007, p. 141) acrescenta que

assim como não prepara as hibridizações conscientes entre verbal e visual na escrita que são, em todo caso, cada vez mais importantes nos letramentos de maior prestígio social, a alfabetização ou, de forma mais ampla, as práticas de letramento escolarizadas, não são hoje voltadas para o desenvolvimento de uma dimensão crítica nas leituras de imagens.

Apesar de não observarmos muitas ações pedagógicas com jogos educacionais digitais na EJA, percebemos que eles já estão sendo utilizados na educação, uma vez que seus benefícios têm sido demonstrados em pesquisas científicas (PINHEIRO, LIMA e ARAÚJO, 2020; ARAÚJO, RIBEIRO e SANTOS, 2012). Pinheiro, Lima e Araújo (2020) investigaram, em um estudo de caso, o aspecto motivacional promovido pelos jogos educativos digitais em alunos do $1^{\circ}$ ano do Ensino Médio para o desenvolvimento da leitura. Os autores constataram que esse aspecto proporcionou o desenvolvimento da leitura, pois os jogos utilizados na pesquisa deixaram os alunos mais motivados e concentrados na leitura e nas atividades propostas. Corroborando as ideias dos pesquisadores, acreditamos no potencial pedagógico desses recursos, pois eles podem tornar a aprendizagem mais leve, especialmente, para estudantes da EJA que, geralmente, passam o dia todo trabalhando.

Savi e Ulbricht (2008) elencam alguns benefícios dos jogos educacionais para os processos de ensino e aprendizagem. No entanto, os autores ressaltam que os jogos não devem se concentrar em um desses elementos para não perder sua atratividade. $O$ primeiro benefício citado pelos autores é o efeito motivador, pois os jogos, por si só, já atraem olhares, seduzindo o jogador quando este é divertido e dinâmico. Relacionado a esse benefício, o jogo também possibilita uma maior facilidade para o aprendizado, já que pode desenvolver raciocínio e memorização, facilitando também o aprimoramento de habilidades cognitivas porque o educando precisa elaborar estratégias para os desafios e resolver problemas. Além do mais, muitos jogos proporcionam socialização, pois permitem ao educando uma relação virtual e uma aproximação real com colegas, com o auxílio de alguém que se dispõe a ajudar ou quando compartilha suas experiências. No jogo, também é possível melhorar a coordenação motora, pois o próprio contato com a máquina ou ferramenta exige o domínio motor ou estimula a coordenação.

Conforme o exposto, sugerimos que o professor deva procurar jogos digitais educacionais para tornar suas aulas mais lúdicas, atrativas e desafiadoras, observando 
esses elementos ou outros considerados por outros autores, para desenvolver sua prática. Sendo assim, o educador deve buscar recursos inovadores para suas metodologias, avaliando-os criteriosamente, pois jogos que reproduzem métodos tradicionais de atividades mecânicas não condizem com sua concepção, uma vez que eles representam dinamismo e assumem práticas menos rígidas de aprendizagem. Dessa forma, apresentamos, na seguinte seção, uma experiência com o uso de um jogo educacional digital com alunos da Educação de Jovens e Adultos, a fim de observarmos seu potencial pedagógico para ampliação dos processos de alfabetização e letramentos desse público.

\section{Metodologia}

Esta seção aborda o percurso metodológico da pesquisa, apresentando o tipo de pesquisa, o campo do estudo, os participantes envolvidos, os instrumentos e técnicas aplicados para coleta dos dados.

\subsection{Tipo de pesquisa}

Esta pesquisa possui uma abordagem qualitativa, pois requer 0 uso de procedimentos descritivos de comportamentos, sentimentos e expressões, para que possa ser compreendida a investigação da utilização de jogos digitais educativos nos processos de alfabetização e letramentos de alunos que cursam a modalidade de Educação de Jovens e Adultos no Ensino Fundamental. Realizamos, portanto, uma análise pela ótica do desenvolvimento da atividade proposta e da receptividade da mesma por parte dos alunos.

Esta investigação é, ainda, exploratória, já que intenta compreender um fenômeno pouco conhecido, pois, como afirma Gray (2012, p. 36), esses estudos "buscam explorar o que está acontecendo e fazer perguntas a respeito. São especialmente úteis quando não se sabe o suficiente sobre um fenômeno. Portanto, um estudo exploratório pode ajudar a decidir se vale a pena pesquisar a questão ou não". Sendo assim, esta é uma pesquisa exploratória de participação ativa, planejada, na qual se pretende uma investigação das práticas pedagógicas, para que, se atestado os benefícios, o objeto estudado (o jogo digital Xote da Preservação) seja apresentado como possibilidade pedagógica para os professores.

\subsection{Campo de estudo e participantes da pesquisa}

Esta pesquisa aconteceu na cidade de Tauá-CE, município que possui o título de Cidade Digital, por ser um dos pioneiros na inclusão digital para sua população. Tauá tem, em suas escolas, Laboratórios Educacionais de Informática (LEIs) que são frequentados periodicamente por alunos do ensino regular, com professores específicos para as aulas e um computador por aluno, para que todos tenham acesso igual à prática. No entanto, diferentemente do Ensino Fundamental regular, em que há um grupo de trabalho voltado aos laboratórios educacionais de informática, quando se trata de EJA, o uso do espaço é opcional pelo professor, não havendo propostas pedagógicas que o incentive, segundo informações do diretor da escola pesquisada. 
A escola em que se deu a pesquisa pertence à rede pública municipal de ensino e contempla o Ensino Fundamental, durante o dia e, à noite, a Educação de Jovens e Adultos. Esta instituição está inserida em um contexto de vulnerabilidade social, criminalidade, falta de saneamento e pouco desenvolvimento. Os participantes desta pesquisa $^{1}$ são adultos que frequentam a modalidade EJA e que, em sua maioria, correspondem a alunos que, ainda jovens, não tiveram acesso à escola, em seu período regular. Esses discentes não retomaram os estudos antes porque precisaram trabalhar e abdicaram desse direito. Também fez parte da pesquisa o(a) professor(a) da referida turma. Este(a) tem formação em Ciências com habilitação em Física e Matemática e é docente na EJA desde 2015. Atualmente, leciona em outra escola, durante o dia e, à noite, assume essa turma de Educação de Jovens e Adultos.

Nossa intenção era realizar a pesquisa com todos os discentes matriculados na turma, porém, muitos alunos se evadem durante o ano letivo. Segundo o (a) professor (a), dos 15 (quinze) alunos que, obrigatoriamente, devem ser matriculados em uma turma para ser criada, 8 (oito) ou 9 (nove) frequentam as aulas. No dia da aplicação da atividade, apenas 5 (cinco) alunos compareceram. Esses são os que frequentam assiduamente as aulas, conforme informou o(a) professor(a). São trabalhadores de diversos setores: pedreiro, auxiliar de serviços gerais, vigilante e dona de casa. Os referidos alunos cursam o primeiro segmento da EJA, que corresponde, nesta turma, ao $1^{\circ}, 2^{\circ}$ e $3^{\circ}$ anos do Ensino Fundamental. Os alunos participantes têm entre 34 (trinta e quatro) e 61 (sessenta e um) anos de idade.

Para primeiro contato, foi realizada uma visita à sala de aula, onde pudemos apresentar o projeto da pesquisa e convidar alunos e professor(a) para participarem. Apresentada a proposta para os participantes, eles não souberam informar um assunto que gostariam de ver em um jogo, talvez por não entenderem como este se dá, visto que é algo inédito para eles. Como não surgiu indicações, citamos as notícias que evidenciavam as queimadas e o desmatamento na Amazônia naquele momento ${ }^{2}$. Foi o ponto de partida para que eles expusessem suas opiniões e foi possível perceber que era um assunto sobre o qual eles demonstravam preocupação e interesse. Decidimos, a partir disso, criar um jogo digital educacional que retratasse os problemas ambientais que se destacam em nossa sociedade.

\subsection{Instrumentos e técnicas}

Destacamos aqui os instrumentos e técnicas que utilizamos desde a chegada ao campo de investigação, o objeto de estudo e os procedimentos de aplicação e coleta de dados, como diário de bordo e entrevista.

1 O projeto desta pesquisa, por lidar com seres humanos, foi submetido ao Comitê de Ética em Pesquisas com Seres Humanos da Universidade Estadual do Ceará (UECE) e obteve aprovação pelo parecer $n^{\circ}$ 3.483.254.

2 No período em que foram realizados os primeiros contatos com a turma, o Brasil estava vivenciando, na Floreta Amazônica, um grande aumento no índice de queimadas e desmatamentos, realizados sem autorização de órgãos ambientais. 


\subsubsection{Observação in loco}

No dia da aplicação do jogo, utilizamos a sala dos professores, já que o laboratório de informática da escola estava impossibilitado de ser utilizado por problemas técnicos. Sendo assim, levamos um notebook para cada discente realizar as atividades do jogo. Os alunos tinham revelado, anteriormente, que não utilizavam computadores, por isso, antes do jogo, eles tiveram um desafio para se familiarizarem com o mouse e o touchpad, concentrando-se nesses dois instrumentos, pois o jogo procede a base de cliques, sem utilizar o teclado. A atividade consistia em clicar nas formas coloridas que iam aparecendo na tela do computador e, à medida que clicavam, as formas iam mudando de posição e diminuindo o tamanho.

Após concluído o desafio e exposto para eles o assunto tratado no jogo, era hora de começar a jogar. Durante a execução desta prática, utilizamos o diário de bordo como um dos instrumentos de coleta de dados, pois acreditamos que as situações ocorridas, como as falas, reações e a interação dos alunos com o computador, contribuem com a investigação, uma vez que as emoções de um jogador são expressas durante a prática do jogo, pois estas são momentâneas e precisam ser registradas para compreendermos a relação estabelecida entre objeto e indivíduo.

\subsubsection{Jogo digital educacional Xote da Preservação}

A partir da conversa que tivemos com os participantes da pesquisa, criamos um jogo que focasse em questões ambientais. Além disso, para criar o jogo digital educacional, com base no estudo teórico feito na seção anterior, escolhemos a canção Xote Ecológico que servirá como base para contextualização do estudo. Selecionamos esta música porque ela apresenta várias consequências da poluição do ar, da água e do solo para nossas vidas, que limitam o uso desses recursos naturais para nossa sobrevivência, e também porque é de autoria de Luiz Gonzaga, um importante representante da música nordestina, já que o público-alvo mora no Sertão do Ceará. Para construirmos o jogo, baseamo-nos nas informações do(a) professor(a) sobre o nível de escrita dos alunos. Segundo este profissional, os níveis variavam "de alunos que estavam no processo inicial de alfabetização àqueles que já conseguiam ler textos curtos".

O jogo, denominado Xote da Preservação, se desenvolve a partir da referida canção de Luiz Gonzaga, conforme percebemos na capa (Figura 1). Nela, podemos ver o nome do jogo, um plano de fundo temático referente ao assunto tratado, uma sanfona em alusão à canção e seu intérprete, Luiz Gonzaga. A seta amarela, abaixo do canto direito, indica que o jogador vai começar a jogar, a partir da tela seguinte. Destacamos que, em todas as telas, há um áudio dos textos que são apresentados e da instrução, indicando o que o jogador deve fazer para dar continuidade ao jogo. 
Figura 1: Capa do jogo Xote da Preservação.

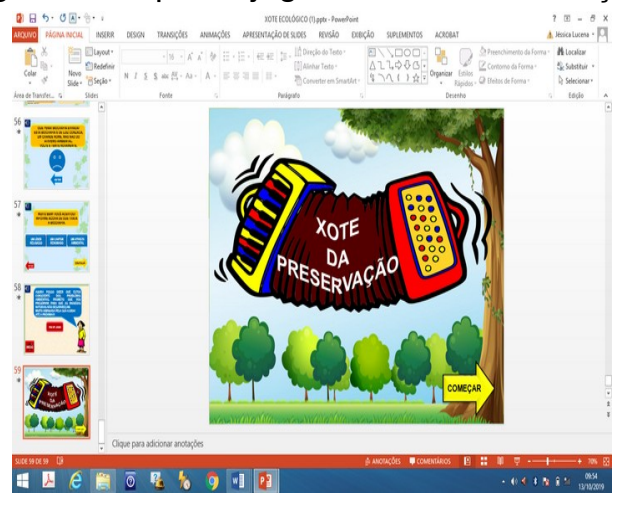

Fonte: Elaborado pelos autores.

Na Figura 2, apresentamos a personagem Luíza, uma senhora que desconhece os problemas ambientais e as formas de preservação, e a narrativa do jogo, a qual apresenta a missão do jogo, que consiste em conscientizar Luíza sobre questões ambientais. Na Figura 3, está um vídeo com a canção Xote Ecológico, de Luiz Gonzaga, como podemos perceber nas Figuras 2 e 3 :

Figura 2: Personagem e missão do jogo.

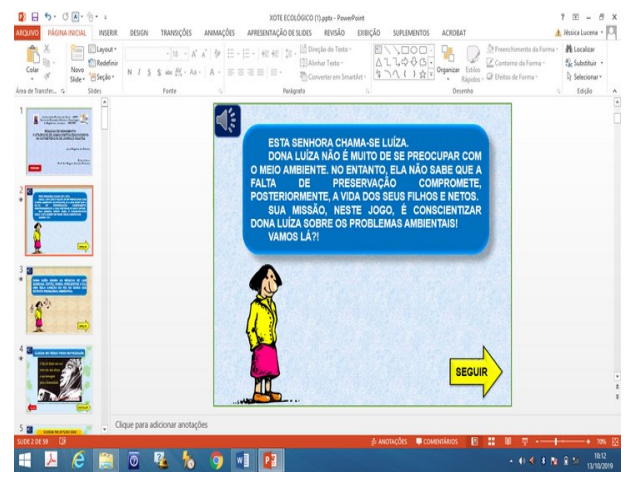

Fonte: Elaborado pelos autores.
Figura 3: Vídeo da canção Xote Ecológico.

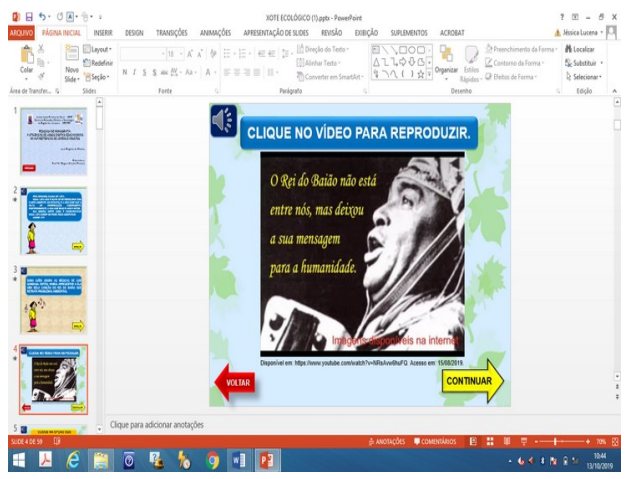

Fonte: Elaborado pelos autores.

$\mathrm{Na}$ Figura 4, buscamos explorar a interpretação dos alunos, para isso, questionamos sobre qual é o principal assunto da canção. Em todas as opções do jogo, quando o aluno clica na resposta errada, a palavra fica na cor vermelha e clicando na correta, verde. Na Figura 5, podemos ver uma estrofe da canção com algumas lacunas, nas quais os jogadores deverão preenchê-las nas telas seguintes. 
Figura 4: Assunto da canção.

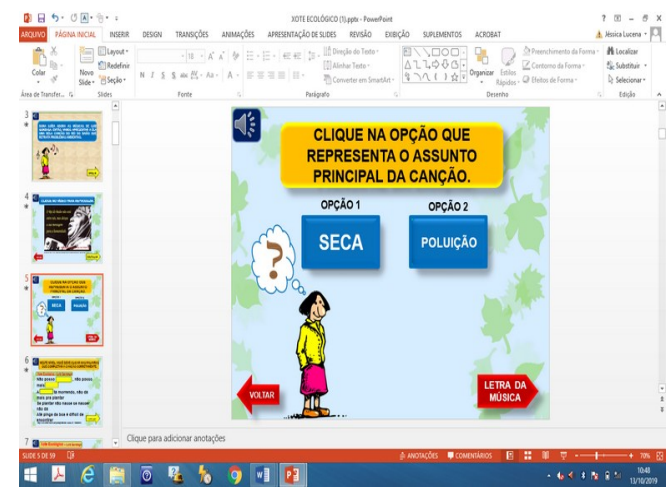

Fonte: Elaborado pelos autores.
Figura 5: Letra da canção lacunada.

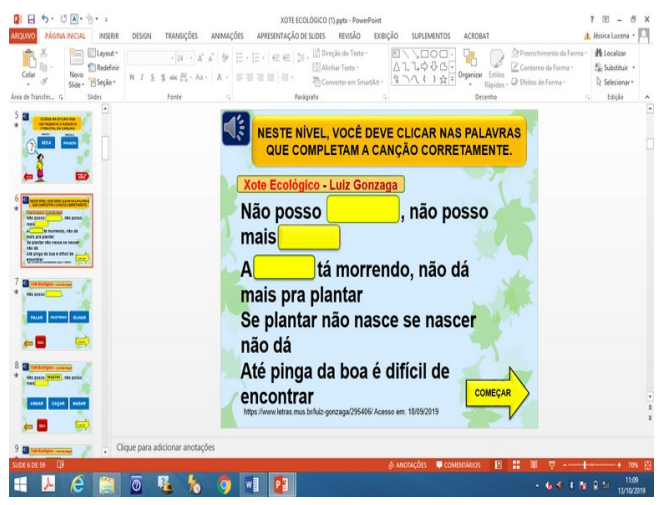

Fonte: Elaborado pelos autores.

$\mathrm{Na}$ Figura 6, podemos ver o segundo verso da canção com uma lacuna e, mais embaixo, três palavras, das quais apenas uma completa o verso corretamente. Ainda na figura 6 , temos o botão dica, que, quando clicado, mostra uma imagem relacionada à resposta correta, como podemos ver na Figura 7. Essa opção se faz necessária, pois muitos alunos podem estar em dúvida quanto à resposta.

Figura 6: Completar a letra da canção.

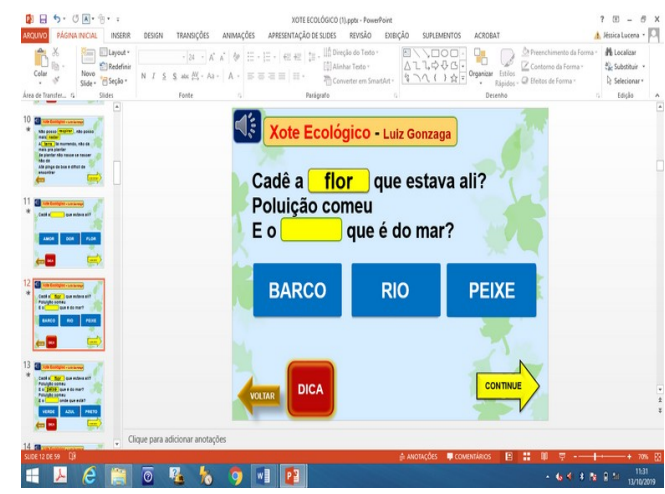

Fonte: Elaborado pelos autores.
Figura 7: Dica.

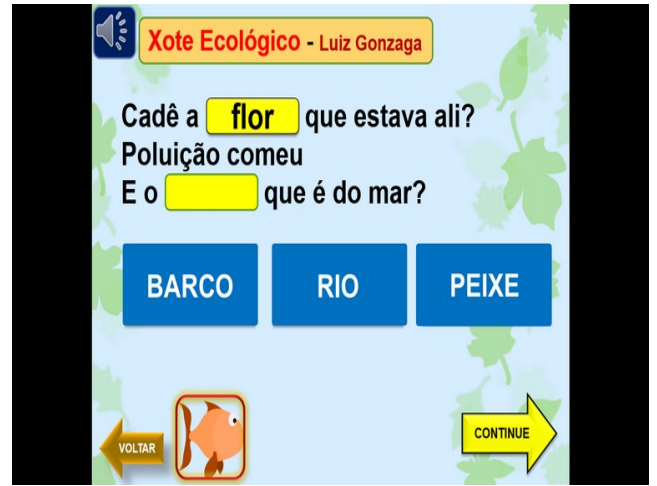

Fonte: Elaborado pelos autores.

Na Figura 8, o desafio é formar a palavra que aparece em destaque na imagem. As palavras, neste nível, são sol, céu e fome. Para formar a palavra, o jogador deve clicar nas formas onde está escrito "clique aqui" e cada forma contém várias letras. Assim, o jogador deixa apenas aquelas que ele considera corretas na escrita da palavra. 
Figura 8: Formar palavras.

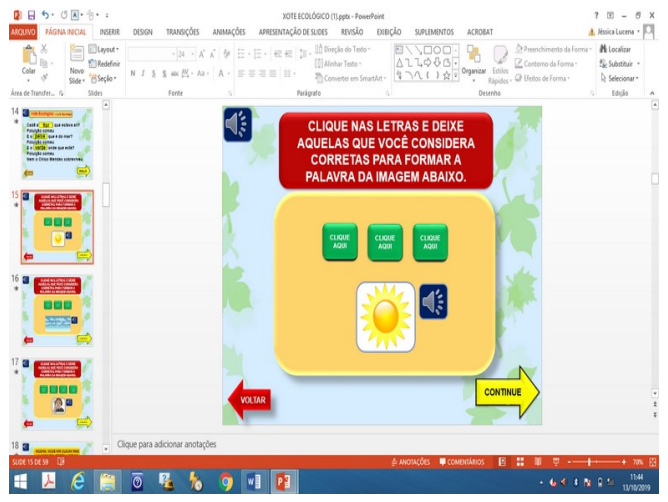

Fonte: Elaborado pelos autores.

O próximo desafio é clicar na letra que completa a palavra corretamente. Na Figura 9, a palavra mato está sem sua última letra, o jogador deve clicar em uma das três opções a qual ele considera correta. Clicando nas letras incorretas, elas desaparecem, clicando na correta, a tela é direcionada ao feedback positivo, indicando que o jogador acertou e revelando a palavra por completo, como podemos ver na Figura 10.

Figura 9: Completar com as letras.

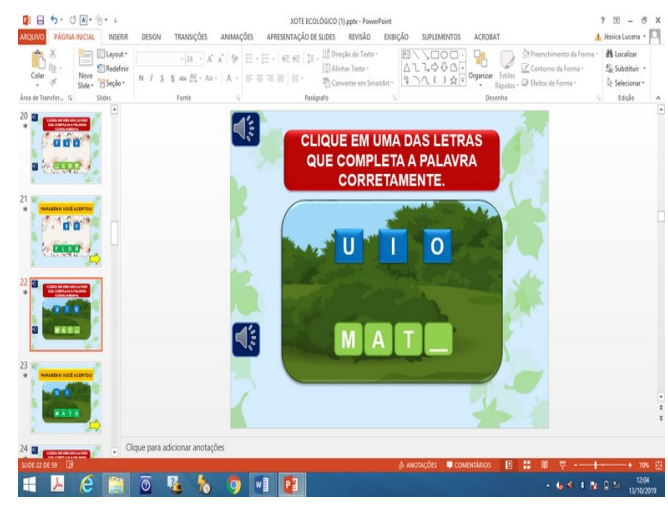

Fonte: Elaborado pelos autores.
Figura 10: Tela de feedback.

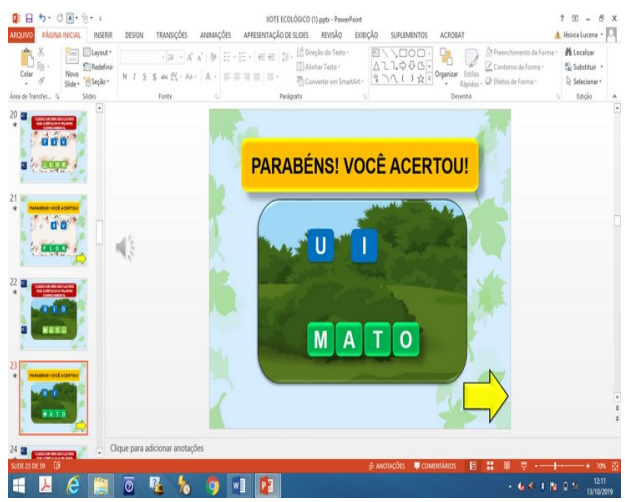

Fonte: Elaborado pelos autores.

No nível seguinte, os jogadores completam as palavras com sílabas, em vez de letras. As ações se sucedem assim como no nível anterior. As palavras escolhidas para este nível foram roça, inverno, seca e chuva e, como observamos nas Figuras 11 e 12, ao fundo, aparece a imagem do açude Cedro, em Quixadá, por ser um dos maiores e mais conhecidos açudes do estado do Ceará. 
Figura 11: Completar com as sílabas.

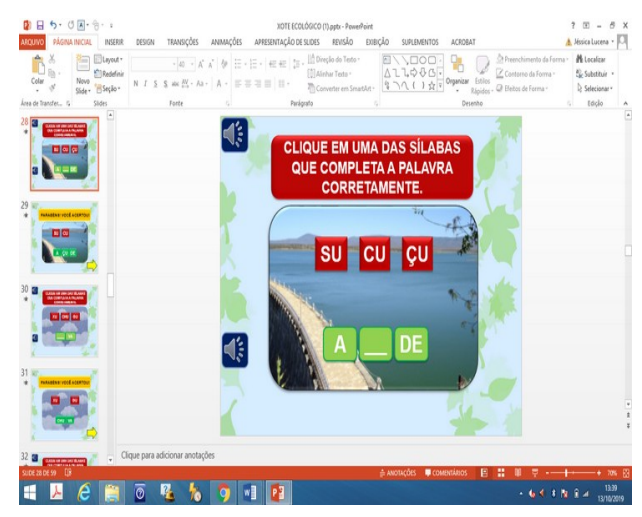

Fonte: Elaborado pelos autores.
Figura 12: Tela de feedback.

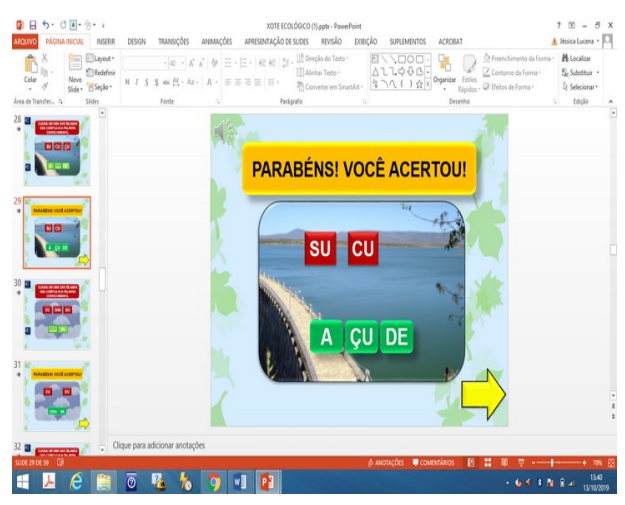

Fonte: Elaborado pelos autores.

No nível seguinte (Figura 13), o desafio é clicar apenas nas palavras que representam problemas ambientais, pois Luíza não sabe identificá-los. Ao clicar nas palavras inadequadas, estas fazem um barulho de explosão e ficam na cor vermelha, em verde, indica resposta correta. O próximo desafio, na Figura 14, é mostrar para Luíza como separar o lixo de acordo com a lixeira apropriada, na coleta seletiva.

Figura 13: Problemas ambientais.

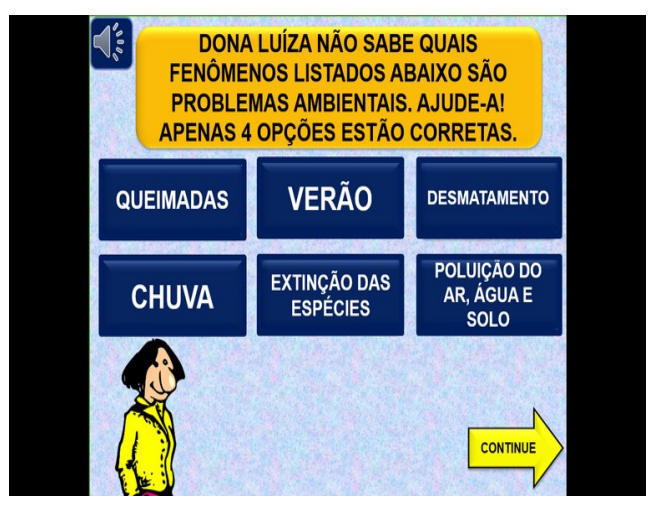

Fonte: Elaborado pelos autores.
Figura 14: Coleta seletiva.

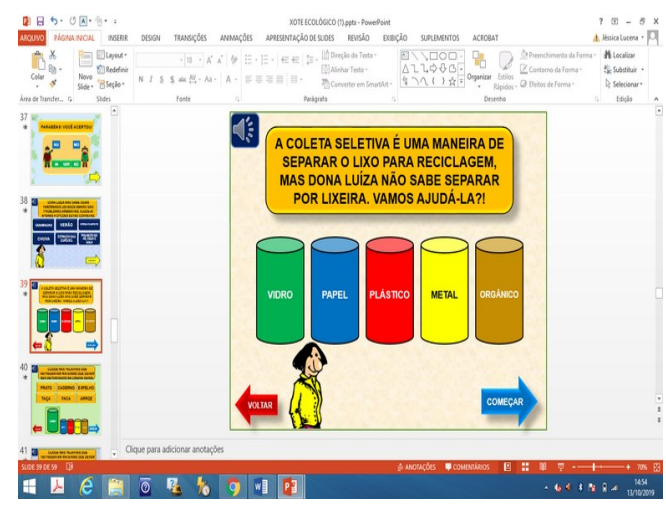

Fonte: Elaborado pelos autores.

Para alcançar o objetivo do desafio da coleta seletiva, o jogador deve clicar apenas nas palavras que representam matérias que devem ser colocados em cada lixeira, identificadas com nomes e cores diferentes, como destacamos nas Figuras 15 e 16 . Ao clicar nas palavras adequadas, elas ficam na mesma cor da lixeira, ao clicar nas inapropriadas, se ouve uma explosão. 


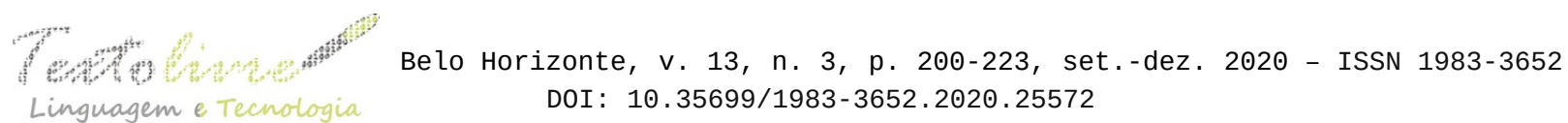
DOI : $10.35699 / 1983-3652.2020 .25572$

Figura 15: Coleta seletiva: vidro.

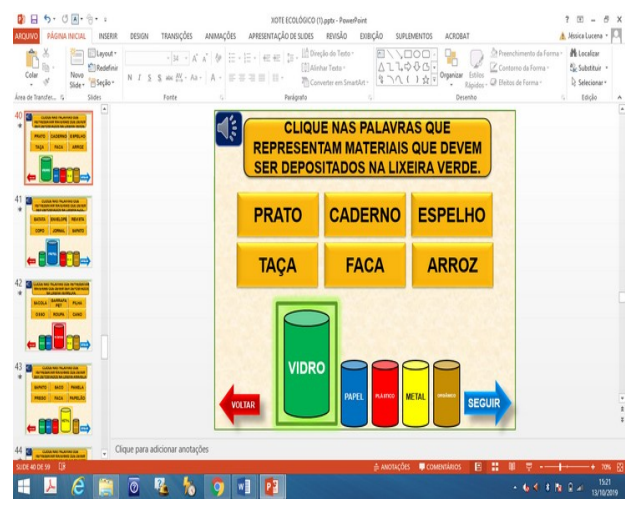

Fonte: Elaborado pelos autores.
Figura 16: Coleta seletiva: papel.

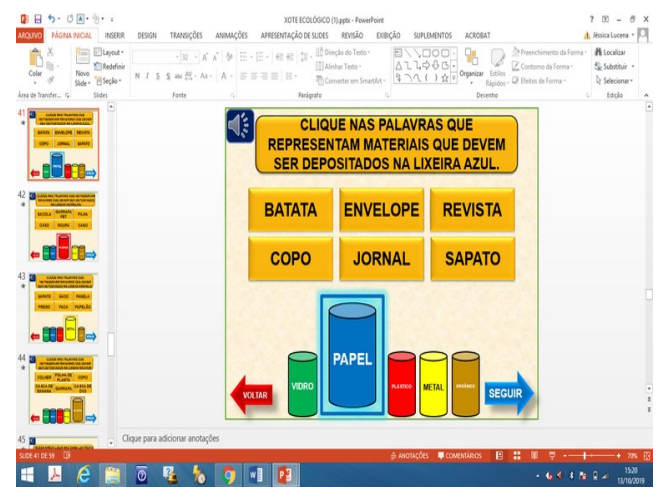

Fonte: Elaborado pelos autores.

O último nível do jogo informa que a personagem Luíza não sabe ler muito bem, dessa forma, o aluno/jogador deve ler os textos para ela e identificar quais destes citam questões relacionadas ao meio ambiente. Este nível é composto por quatro gêneros textuais: bilhete, carta, notícia e biografia.

Na Figura 17, temos dois bilhetes e o jogador deve clicar no texto que apresenta preocupação com o meio ambiente. Ao errar, ele é direcionado à tela de feedback instrutivo (Figura 18), o qual descreve o motivo do erro. O jogador retorna à questão e, ao acertar a resposta, é direcionado à tela onde deve informar, dentre as três opções, o assunto tratado naquele texto (Figura 19). Se o aluno tem dificuldade em ler os textos, os áudios, abaixo de cada texto, podem ser acionados para auxiliá-lo. O jogo segue usando os mesmos procedimentos com os outros gêneros.

Figura 17: Bilhete.

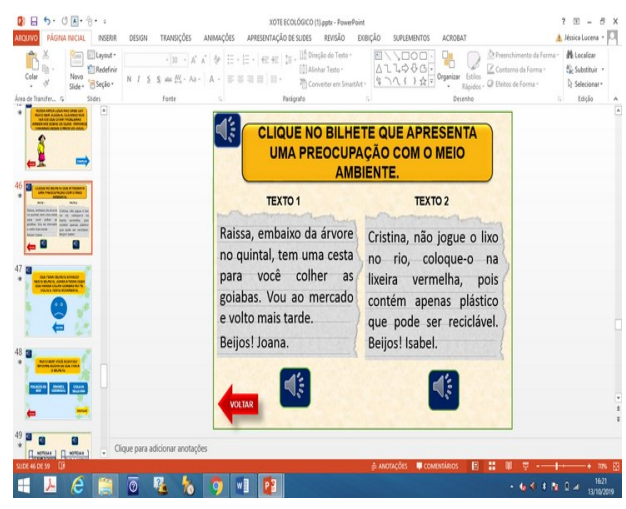

Fonte: Elaborado pelos autores.
Figura 18: Feedback instrutivo.

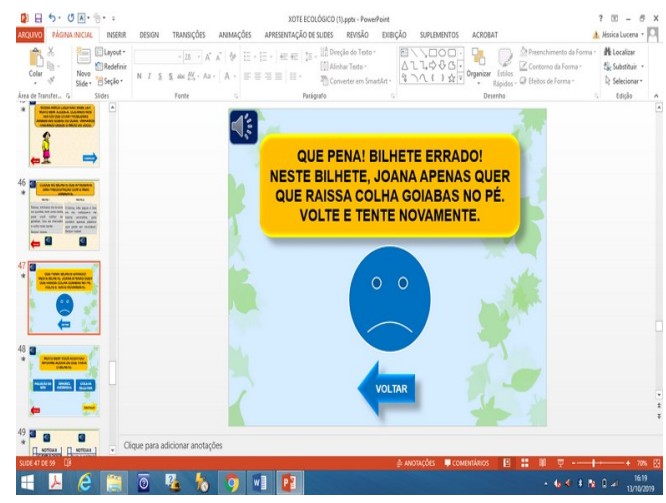

Fonte: Elaborado pelos autores. 
Figura 18: Assunto do bilhete.

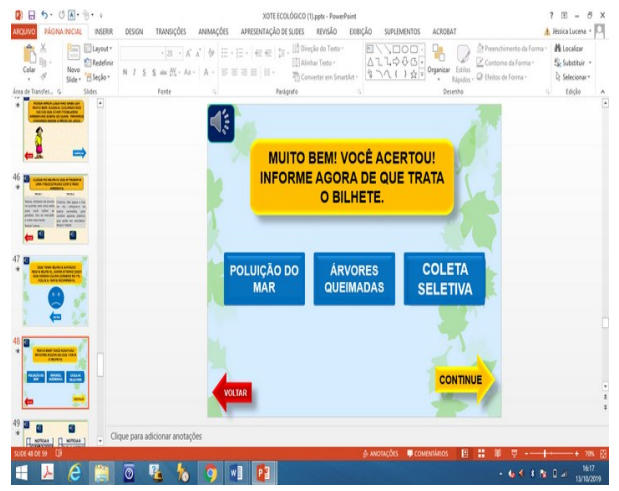

Fonte: Elaborado pelos autores.

$\mathrm{Na}$ última tela do jogo, podemos ver que a personagem Luíza revela estar consciente dos problemas ambientais e afirma que vai cuidar mais do meio ambiente. Dessa forma, Luíza agradece pela ajuda do jogador e finaliza o jogo.

Figura 19: Tela de fim de jogo.

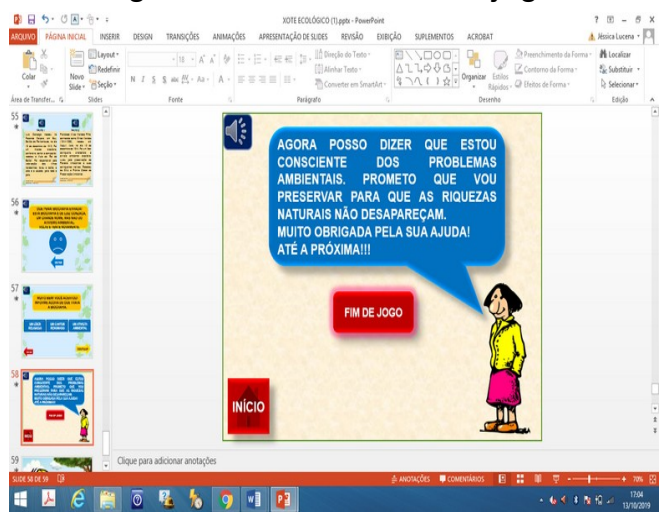

Fonte: Elaborado pelos autores.

\subsubsection{Entrevista semiestruturada}

A escolha pela entrevista semiestruturada aos alunos e professor(a) como instrumento de coleta de dados, se deu por sentirmos necessidade de que estes aprofundem suas respostas, pois, como afirma Gray (2012, p. 302), "isso é vital quando se assume uma abordagem fenomenológica em que o objetivo é explorar os sentidos subjetivos que os respondentes atribuem a conceitos ou eventos". Com vistas a registrar sua experiência sobre aquela prática, as perguntas aos alunos são direcionadas diretamente ao jogo digital utilizado e, também, sua relação com a máquina e, ao professor(a), são perguntas relacionadas a sua percepção acerca do que viu e, também, sua prática profissional com uso das tecnologias.

Após término do jogo, de volta à sala de aula, as entrevistas foram realizadas com um participante por vez e utilizamos um smartphone para fazer as gravações. Para identificar individualmente as respostas dos participantes, visando ao processo de análise, numeramos e nos referimos aos alunos como (A1), (A2), (A3), (A4) e (A5), ao professor(a), como (P). Os dados serão apresentados e discutidos na seção a seguir. 


\section{Análise dos dados}

A educação, de maneira geral, já demonstra adaptação e esforços nas práticas escolares subsidiadas pelas tecnologias digitais. Sendo assim, acreditamos que o jogo digital educacional, em turmas de EJA, seja uma ferramenta pedagógica que une objetivos educacionais e insere os alunos em novas práticas alicerçadas à tecnologia. Dessa forma, apresentaremos e analisaremos, a seguir, os dados coletados sobre a potencialidade do jogo digital educacional nos processos de alfabetização e letramentos de jovens e adultos.

\subsection{Relação aluno-máquina}

Considerando que os alunos que frequentam a EJA hoje são aqueles que, em sua maioria, não tiveram acesso às tecnologias em sua juventude, pois estas só se tornaram acessíveis apenas neste século, este público, possivelmente, enfrenta maiores dificuldades ao se deparar com os diversos aparelhos digitais que utilizamos atualmente. Isso é reflexo da desigualdade social que o público da EJA sofre em relação aos demais, pois, representa jovens e adultos que se evadiram da escola em decorrência, principalmente, da busca por trabalho.

Desse modo, como os alunos revelaram, através das primeiras interlocuções da pesquisa, não terem contato com computadores fora da escola e não possuírem esse aparelho em casa, propomos um teste, no qual foi possível explorar a coordenação motora, uma espécie de treinamento que possibilitaria ao aluno adquirir certo domínio motor. A atividade consiste em clicar em círculos grandes e, ao passo que clicavam, as formas iam mudando de posição e diminuindo o tamanho. Na Figura 20, é possível ver quatro telas como exemplo desse exercício motor:

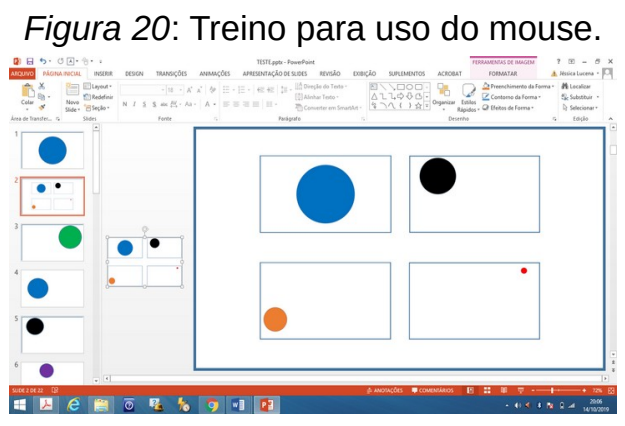

Fonte: Elaborado pelos autores.

A princípio, tínhamos receio de que os alunos tivessem dificuldade em controlar o mouse e o touchpad, no entanto, o que observamos foi a destreza com que eles realizaram essa atividade, demostrando ótima coordenação motora, inclusive nas formas menores. Um aluno chama atenção por sua habilidade com o mouse, passando a impressão de que este fazia uso desses aparelhos frequentemente. Perguntamos se ele faz uso do computador, no entanto, ele revela que "o computador... só assim... abrir assim, mas mexer mesmo, mexi umas duas vez ou três, só. Mexer assim eu sei, eu controlo o mouso do computador, agora eu num sei muito é botar ele pra..." (A4). 
Entendemos a partir da fala desse aluno que, "mexer", é manusear o mouse depois que o computador está ligado, o que demonstrou que consegue fazer, no entanto, quando ele diz que "eu num sei muito é botar ele pra...", concluímos que ele se refere a não estar apto a realizar pesquisas, buscar ferramentas e programas. Acreditamos que, com o uso de jogos digitais educacionais, além das aprendizagens dos conteúdos que neles são explorados, é possível, segundo Paula (2015, p. 87-88), "o desenvolvimento de competências relacionadas aos jogos digitais $\mathrm{e}$, mais amplamente, às mídias e às tecnologias digitais".

Quando perguntados sobre que tipo de aparelhos digitais usavam e para quê, os alunos informaram utilizar apenas o celular para as necessidades de comunicação mediadas por tecnologias. Essa constatação nos leva para o fato de que, apesar da existência dos celulares, atualmente, o acesso à internet ainda é limitado. Sendo assim, observamos que o acesso ao telefone para aprendizagem e informação nem sempre é possível para um público com dificuldades socioeconômicas, por isso, a escola deve proporcionar esses recursos. No entanto, conforme Pinheiro (2018, p. 619) assevera, as atividades com tecnologias "não podem ser somente uma transferência do impresso para o virtual, pois é necessária a compreensão de que a inserção das tecnologias nas sociedades possibilitou mudanças nas formas de interagir e se informar".

Perguntado ao professor(a) da turma se usa o laboratório de informática para as aulas, ele(a) respondeu que dificilmente utiliza. No entanto, revelou que havia uma iniciativa na qual um responsável pela autarquia municipal de trânsito dava aulas sobre legislação através de simulados e essa experiência acontecia no laboratório de informática, pois os simulados eram online. O objetivo desses testes era ajudar os alunos com os conteúdos de legislação de trânsito, pois estes demonstraram interesse e necessidade devido à prova que iriam realizar como requisito obrigatório na obtenção da carteira de habilitação.

O(a) professor(a) ainda revelou que essa prática ocorreu um dia por semana, durante três semanas. Sendo assim, remetemo-nos à fala do A4, citada anteriormente, ao afirmar que "o computador... só assim... abrir assim, mas mexer mesmo, mexi umas duas vez ou três, só". Compreendemos que a experiência vivenciada com o computador em três oportunidades foi realizada nesse simulado. Constatamos que esta atividade é apenas uma transferência do impresso para o virtual e desconsidera as potencialidades pedagógicas do computador. Sendo assim, concordamos com Pinheiro (2018, p. 615-616) ao afirmar que "mesmo quando os alunos usam ferramentas tecnológicas que abrem diversas possibilidades de práticas sociais, essas tecnologias são utilizadas para reproduzir velhas metodologias".

Embora toda iniciativa à prática das tecnologias seja louvável, atividade em formato de simulado está muito abaixo das potencialidades que as ferramentas tecnológicas podem oferecer, pois este seria somente uma transferência do impresso para o digital, desconsiderando as mudanças que as tecnologias proporcionaram nos modos de aprender, se comunicar e se informar. Um enfoque mais dinâmico e lúdico, possível através do computador, desta vez utilizando jogos digitais educacionais, será apresentado e analisado a seguir. 


\subsection{Jogo digital educacional}

Os jogos digitais são fontes de diversão e prazer, porém, muitas pessoas não os veem como algo positivo e sim como uma prática que vicia, estimula a violência, distrai a atenção e torna o indivíduo antissocial. Sabendo que crianças e adolescentes são os maiores praticantes, perguntamos, aos alunos jovens e adultos e ao professor(a), o que achavam dos jogos digitais e todos demonstraram preocupação com a violência dos jogos e foram unânimes com relação à supervisão que os pais devem ter com relação a esse tipo de entretenimento. Vejamos, a seguir, o depoimento de alguns participantes:

(A1): "eu já vi passano alguns que é perigoso. Eu, eu tenho dois filho... um, ele fica mostrano, aí a gente orienta eles que esses não pode que é perigoso".

(A2): "é... dependendo do jogo em si. Se é para criança, né, deve ter a manutenção dos pais envolvida, né".

(A3): "Tem uns que são bom, tem outros que não são. É tanto que, os meus menino eu num deixo jogar... eu num posso acompanhar direto, eu acho melhor eles não jogar".

(P): “(...) Na verdade, entretenimento, todo mundo merece, mas sem excessos. Tem uns muito violentos... meus meninos tavam jogando esse Free Fire e, assim, matam pessoas, vê o sangue e tudo, realmente são jogos que estimulam a violência, né, são realmente preocupantes".

Corroborando as falas dos participantes, concordamos que, muitas vezes, crianças e jovens, ao jogar em excesso, ficam dependentes dessas tecnologias e apresentam comportamento antissocial, pois destacamos a forma como alguns jogos digitais estimulam a violência gerando preocupação para pais e professores. Como citado em uma das falas, Free Fire é a representação mais atual desse tipo de jogo, pois consiste em personagens que precisam manter-se vivos até o fim da missão e, para isso, buscam armas de combate para eliminar os demais jogadores. Sendo assim, concordamos com Pinheiro, Cavalcante e Amorim (2018, p. 659) quando defendem "o uso moderado dos jogos digitais e compreendem que as escolas e os pais precisam observar 0 comportamento de seus alunos/filhos e conscientizá-los de que devemos usufruir de diversas atividades cotidianas, reais e virtuais".

Sabendo a opinião dos alunos sobre os jogos digitais, perguntamos, em seguida, sobre jogos digitais educacionais e pudemos perceber uma visão positiva acerca destes. Acreditamos que essa visão se deu com base na conversa informal que tivemos antes da produção e aplicação do jogo, na qual explicamos o objeto e os procedimentos para esta pesquisa, e também na experiência com o jogo Xote da Preservação. Destacamos, a seguir, algumas respostas:

(A2): "ah, eu acho ótimo, principalmente... eu gostei muito desse. Aprende a manusear, a interagir, coisa que é difícil pegar em computador. E eu levei super bem, até porque, o jogo foi bem gostoso, eu entrei no jogo e... fui (risos).".

(A4): "aquele é bom. Eu achei ele bom. Pra ensinar é bom".

(A5): "é bom, pra quem quer, né, porque já tem outros que, os menino novo que tem hoje na nação, que nós tamo vivendo hoje, se botar aquele eles não vão ligar muito não. Mas se for jogo 'pa, pa, pa' (ele se referiu aos tiros presentes em muitos jogos violentos) ele já vai gostar, né”. 
$(P)$ : "esses são muito bons. Uma maneira lúdica, que prende a atenção dos adultos, né. E assim, é uma metodologia muito válida, uma maneira de dar uma aula diferente, sair daquela aula tradicional, que hoje em dia é abominada".

Proporcionada essa experiência a eles, percebemos a satisfação em estar vivenciando uma nova prática, tanto que, logo no início do jogo, um dos alunos nos pede que tire foto sua em frente ao computador, evidenciando que estava utilizando a máquina. Destacamos esse momento, pois, para aquele participante, isso representa uma nova experiência de inserção em práticas de letramento digital e, quando perguntado como se sentiu jogando um jogo digital, este revela que "me senti bem, aprendendo uma coisa nova" (A3). Compreendemos que, além dos objetivos que estão presentes no jogo, ele aprende a utilizar uma nova tecnologia, assim como também cita o A2, quando diz que "aprende a manusear, a interagir". Dessa forma, concordando com Pinheiro (2018, p. 619), percebemos que esses recursos "são ferramentas importantes no ambiente escolar porque são atraentes [...] e auxiliam no desenvolvimento e aprendizagem dos alunos, principalmente por oferecer diversificadas possibilidades de interação e construção de sentidos".

Em seguida, ao serem questionados sobre o que acharam do assunto tratado no jogo Xote da Preservação, todos os discentes, em suas respostas, refletiram sobre questões ambientais. Vejamos alguns depoimentos:

(A2): "Eu gostei muito desse. Fala muito a respeito do planeta que, hoje em si, quase ninguém liga pra isso, é só trabalhar e ganhar dinheiro".

(A4): "É bom, porque tem muita gente que não sabe o negócio do lixo, tem gente que pega um lixo e joga dentro da lagoa... Tem que pegar o lixo, juntar cada um e botar em seu lugar, como aqui a gente não tem a coleta de tudo separado, a gente junta tudo e joga fora".

(A5): "É bom pra pessoa não soltar vrido na rua, plástico, sacola. A gente não dá fé do tamanho do estrago, mas se você passar a conhecer um pouco, cê sabe".

Percebemos, a partir da fala dos alunos, a importância desta pesquisa em trazer temáticas do cotidiano e retratá-las no jogo, pois isso permite o diálogo entre educador e educando acerca do mundo em que estão inseridos, como afirma Freire (1987). Dessa forma, o jogo digital pesquisado proporcionou uma tomada de consciência que é o ponto de partida para que voltem os olhares para o mundo e possam transformá-lo a partir da conscientização (FREIRE, 2018).

Ao responder à questão referida anteriormente, o(a) professor(a) chama a atenção para outras questões presentes no jogo, conforme podemos perceber na sua fala:

$(P):$ "O que me chamou atenção, além da parte ambiental e conscientização do meio ambiente, através da música, dos textos... foi a questão, também, da facilidade e até ajuda pra eles lerem, né, porque eu tenho alguns alunos que estão no pré-silábico, silábico e eles leem soletrando. Então, realmente, as letras maiúsculas, a questão da atividade que tinha que colocar as sílabas, a primeira letra, foi muito bom pra eles".

$\mathrm{Na}$ fala do(a) professor(a), evidencia-se a alfabetização em Língua Portuguesa, atendendo às necessidades de alunos que estão aprendendo a ler. O jogo objetivou 
alfabetizar em vários níveis: pré-silábico, alfabético e interpretação de textos ${ }^{3}$. Sua proposta é alfabetizar e letrar ao mesmo tempo com uma atividade lúdica, pois ele trabalha a leitura a partir dos problemas ambientais. Observamos o processo de alfabetização realizado com o jogo, considerado aqui como uma prática social, que possibilitou a alfabetização através do letramento, pois, conforme Catelli Jr. (2014, p. 105106), "não basta alfabetizar, é preciso avançar muito mais no processo de letramento de jovens e adultos, para que estes sejam de fato cidadãos de direito, capazes de fazer uso efetivo da leitura e da escrita na vida social".

Sobre o que aprenderam com o jogo, as respostas dos alunos variam entre aprender a ler e preservar o ambiente. Ao(a) professor(a), perguntamos se seria possível aprender a partir de um jogo e ele responde afirmativamente. Vejamos os depoimentos de alguns participantes sobre essas questões:

(A1): "Eu aprendi alguma coisa, assim, montar as palavras, juntar pra poder formar a palavra certa.

(A2): "Aprendi muita coisa. Mas, uma delas, a partir de agora, preservar mais o meio ambiente. Agora, lixo, cada um no seu habitat natural, que eu não fazia".

(P): "Lógico. Sim. Dependendo do conteúdo, né... muitas vezes, o jogo é aplicado só pra um conteúdo, outra vez é interdisciplinarizado com outros conteúdos. Com certeza dá pra aprender muito".

Observando as respostas, constatamos que os alunos revelaram aprender coisas novas, tais como separar o lixo por lixeira, reconhecer a cor determinada da lixeira para cada material. Este conhecimento abre caminhos para a construção dos sentidos e cabe ao professor identificá-los e desenvolvê-los. Sobre ser possível aprender a partir do jogo, o(a) professor(a), em sua fala, apresenta a interdisciplinaridade, que foi a proposta do jogo, pois é uma junção de Língua Portuguesa e o tema transversal meio ambiente. Esse enfoque contextualizado também é visto por Kleiman (2007, p. 6) como vantagem para o professor, pois "é a autonomia que ele ganha no planejamento das unidades de ensino e na escolha de materiais didáticos".

Durante a observação, foi possível percebermos, ainda, o envolvimento dos alunos em várias situações. Em dado momento, o(a) professor(a) se surpreende, pois tenta chamar a atenção de um aluno e ele não percebe de tão concentrado que estava. A esse respeito, Prensky (2001) nos mostra que a ação de jogar exige do jogador um intenso envolvimento. Outro aluno, ao tentar responder à atividade, clica no link incorreto e, irritado, externa a expressão "Grr! Era com S", se referindo à palavra seca, a qual ele escreveu com a letra C. Esse feedback proporcionado pelos jogos permite aos alunos saber se sua ação foi apropriada ou não para aquele momento. No jogo Xote da Preservação, apresentamos um feedback instrutivo, que, segundo Prensky (2001), tem como objetivo apresentar ao jogador o porquê de tal resposta, ou seja, ele é explicativo e apresenta um resultado, explicando como ele deveria proceder. Assim, conforme percebemos no exemplo anterior, o jogador, instruído sobre o erro, tem a opção de corrigilo, voltando e repetindo a jogada.

Outro ponto de destaque que observamos é a socialização da aprendizagem. Os alunos ficavam conversando sobre o jogo e um colega pergunta ao outro se este tinha terminado de ouvir a música; outro comenta com os colegas que verão não é um 
problema ambiental porque é uma das estações do ano; um aluno afirma que, na palavra mata, se trocarmos a letra $A$ por $O$, obtemos mato. Esses momentos de interação e socialização são benefícios dos jogos digitais, conforme afirmam Savi e Ulbricht (2008) e Prensky (2001), pois os alunos estão expressando suas experiências e aprendizagens adquiridas no jogo. O jogo testado tem como enredo uma personagem que desconhece os problemas ambientais e as formas de preservação. Dessa forma, o objetivo consiste em conscientizá-la, pois os alunos são incumbidos de ensiná-la de diversas maneiras. Essa meta proposta corrobora as ideias de Pinheiro, Lima e Araújo (2020) quando afirmam que a motivação dos estudantes para as práticas de leitura pode ser gerada a partir de jogos educativos digitais, pois estes possibilitam o envolvimento na realização de tarefas para uma possível mudança de comportamento. Corroborando essas ideias, um dos alunos destaca que "o que me deu mais atenção foi a Luíza, ela fazer tudo e num saber que o que ela tava fazendo era errado, nera" (A4).

Acreditamos, ainda, que os elementos gráficos e sonoros ajudaram a dar dinâmica ao jogo e, assim, contribuíram para aprendizagem dos participantes da pesquisa, pois esses elementos contribuíram para a apreensão dos sentidos no jogo. Assim, perguntamos o que acharam dos elementos imagem e áudio e eles responderam que

(A1): "ajuda muito. O sol. Aquela senhora. Aí, tudo isso aí, a gente escutou e tem uma dica do caminho, né".

(A2): "ajuda, até porque, nem todo mundo consegue ler rapidamente e a pessoa pode optar por ler ou por escutar ou pode escutar e visualizar".

$(P)$ : "Ajudaram demais. Muito, muito. A questão das dicas, a questão do ouvir, porque eles ouviam e depois iam tentar ler ou então eles estavam ouvindo e lendo junto. Ajudou muito mesmo".

A partir das falas citadas anteriormente, percebemos que as imagens e áudios contribuíram com a prática do jogo. O jogador que não sabe ler ou lê com dificuldades tem a opção de ouvir o áudio e, ao mesmo tempo, acompanhar o texto. Um aluno nos chama atenção, pois tentava ler os textos e, em seguida, ouvia os áudios para comprovar sua leitura. Sobre essa questão, ressaltamos a importância da harmonização entre escrita, imagens e oralidade, pois, segundo Buzato (2007), é cada vez mais necessário que a escola considere a hibridização das diversas linguagens em suas práticas escolares, pois o uso dessas práticas tem cada vez mais prestígio social.

Perguntamos ao docente se esta ferramenta poderia fazer parte da sua metodologia e obtivemos a seguinte resposta: $(P)$ : "Com certeza. Se pudéssemos, realmente, usar pelo menos, uma vez por semana, seria muito importante, muito válido. É uma maneira de tornar as aulas mais dinâmicas, mais atrativas". No entanto, revelou não ter muita habilidade para criar esse tipo de ferramenta, embora já tivesse participado de formações sobre técnicas relacionadas às tecnologias, além do tempo que uma atividade como essa exige para criação. Sendo assim, concordamos com Pinheiro (2018, p. 619) quando afirma que "o acesso às tecnologias digitais não é suficiente para ampliação do letramento digital dos alunos e que a formação dos docentes é um aspecto que não deve ser negligenciado pelas políticas públicas".

Embora o(a) professor(a) tenha revelado pouca habilidade com essas ferramentas, destacou que o referido jogo atende às necessidades dos alunos no que se refere à alfabetização e a conscientização dos fenômenos sociais que afetam toda a população, revelando, portanto, que este é oportuno e viável para os objetivos pedagógicos e pode 
fazer parte da sua prática, conforme podemos perceber na análise final que o docente faz do jogo testado:

$(P)$ : "Realmente, muito didático. A metodologia, assim, foi clara, né, para os alunos, bem lúdico mesmo. A questão das letras maiúsculas de início, isso facilita muito a leitura deles, a separação de sílabas e tratar a transversalidade, uma maneira de conscientizar quanto a preservação. Eu gostei muito".

Considerando o exposto, acreditamos que a formação dos professores é um ponto de partida para práticas contextualizadas na Educação de Jovens e Adultos, pois o professor capacitado tem maior potencialidade de desenvolver ideias e enfrentar desafios. Com uma formação adequada, os docentes podem selecionar bons jogos disponíveis na internet que envolvem o jogador e se mostram como uma ferramenta possível para práticas pedagógicas, pois, destacamos as diversas vantagens do jogo digital educacional (SAVI; ULBRICHT, 2008), que podem trazer a realidade do indivíduo em destaque e conscientizá-lo sobre o mundo que o cerca e, do mesmo modo, inclui-lo digitalmente.

\section{Considerações finais}

Com esta pesquisa, atestamos que o jogo digital educacional Xote da Preservação demonstrou potencial pedagógico com a turma investigada, tanto para alfabetizar letrando os alunos que estão aprendendo a ler, quanto para ampliar os processos de letramentos daqueles que já dominam o código escrito. Evidenciamos que as práticas pedagógicas com auxílio das tecnologias, nesta turma, são poucas e se resumem a exercício de simulados e estes não se mostram desafiadores e atrativos. Como os autores que embasam este trabalho destacam, as tecnologias não devem ser pensadas como reprodutoras de práticas tradicionais, uma vez que dispõem de recursos capazes de tornar as aulas muito mais dinâmicas e contextualizadas.

Percebemos que os alunos são abertos a novas propostas, pois aceitaram prontamente o convite para participar e contribuir com esta investigação. Observamos, ainda, que ficaram animados em participar, revelando que gostam de desafios, já que utilizar o computador como ferramenta educacional era algo novo para eles. Dessa forma, acreditamos que, quando as propostas didático-pedagógicas são mais lúdicas, os sujeitos revelam prazer em aprender, conforme pudemos observar nos participantes desta pesquisa, que demonstraram motivação e envolvimento se divertindo com o jogo.

Conforme o exposto, constatamos que, apesar de nosso objetivo não ter sido ensinar os alunos a manusear um computador, acreditamos que esta pesquisa serviu para estimulá-los a buscar sua inserção no meio tecnológico, pois acreditamos que novas oportunidades são abertas àqueles que fazem uso das tecnologias. Além do mais, verificamos que o jogo digital educacional Xote da Preservação apresenta-se como um recurso metodológico capaz de contribuir para a alfabetização e os processos de letramentos dos alunos e desenvolver sua consciência social, possibilitando a introdução das tecnologias nas práticas educacionais da Educação de Jovens e Adultos. 


\section{Referências}

ARAÚJO, N. M. S.; RIBEIRO, F. R.; SANTOS, S. F. Jogos pedagógicos e responsividade: ludicidade, compreensão leitora e aprendizagem. Bakhtiniana. Revista de Estudos do Discurso, v. 7, n. 1, p. 4-23, 2012. Disponível em: https://www.scielo.br/pdf/bak/v7n1/v7n1a02.

BRASIL. LDB: Lei de Diretrizes de Bases da Educação Nacional. 2. ed. Brasília: Senado Federal, $1996 . \quad$ Disponível em: https://www2.senado.leg.br/bdsf/bitstream/handle/id/544283/lei_de_diretrizes_e_bases_2e d.pdf . Acesso em: 30 jun. 2019.

BRASIL. Lei n.13.005, de 25 de junho de 2014. Plano Nacional de Educação - PNE, Brasília, DF, 26 jun. 2014. Disponível em: http://pne.mec.gov.br/18-planos-subnacionaisde-educacao/543-plano-nacional-de-educacao-lei-n-13-005-2014. Acesso em: 20 jun. 2020.

BUZATO, M. E. K. Letramentos multimodais críticos: contorno e possibilidades. Revista Crop. No $12 / 2007$, p. 108-144.

CATELLI Jr., R. Alfabetização de jovens e adultos no Brasil: de programa em programa. In: MORTATTI, M. R.; FRADE, I. C. S. (org.). Alfabetização e seus sentidos: o que sabemos, fazemos e queremos? São Paulo: UNESP, 2014. p. 91-108. Disponível em: https://www.marilia.unesp.br/Home/Publicacoes/alfabetizacao_ebook.pdf. Acesso em: 31 out. 2019.

FERREIRO, E.; TEBEROSKY, A. Psicogênese da língua escrita. Porto Alegre: Artes Médicas, 1986.

FREIRE, P. Conscientização. São Paulo: Cortez, 2018.

FREIRE, P. Pedagogia do oprimido. 16ª . ed. Rio de janeiro: Paz e Terra, 1987.

GRAY, D. E. Pesquisa no Mundo Real. 2. ed. Porto Alegre: Penso, 2012.

INSTITUTO BRASILEIRO DE GEOGRAFIA E ESTATÍSTICA. Pesquisa Nacional por Amostra de Domicílios, 18 de maio, de 2018. Disponível em: https://agenciadenoticias.ibge.gov.br/agencia-noticias/2012-agencia-de-noticias/noticias/ 21255-analfabetismo-cai-em-2017-mas-segue-acima-da-meta-para-2015. Acesso em: 05 ago. 2019.

KLEIMAN, A. B. O conceito de letramento e suas implicações para a alfabetização. Projeto Temático Letramento do Professor, fev. 2007. Disponível em: http://www.conhecer.org.br/download/ALFABETIZACAO/Anexo3.doc. Acesso em: 22 set. 2019.

PAULA, B. H. de. Jogos digitais como artefatos pedagógicos: o desenvolvimento de jogos digitais como estratégia educacional. 2015. 227 f. Dissertação (Mestrado) - Programa de 
Pós-Graduação em Artes Visuais do Instituto de Artes, Universidade Estadual de Campinas, Campinas, 2015.

PINHEIRO, R. C.; CAVALCANTE, G. R. M.; AMORIM, N. O. Jogos digitais para alfabetização. Domínios de Lingu@gem, v. 12, n. 1, 2018, p. 653-680. Disponível em: http://www.seer.ufu.br/index.php/dominiosdelinguagem/article/view/38614/21982. Acesso em: 21 abr. 2020.

PINHEIRO, R. C. Conceitos e modelos de letramento digital: o que escolas de ensino fundamental adotam? Linguagem em (Dis)curso-LemD, Tubarão, SC, v. 18, n. 3, p. 603622, $\quad$ set./dez. 2018.2 Disponível em: http://www.portaldeperiodicos.unisul.br/index.php/Linguagem_Discurso/article/view/ 7059/4114. Acesso em: 05 maio 2020.

PINHEIRO, R. C.; LIMA, F. A.; ARAÚJO, J. Jogos digitais como motivação para a leitura. Diacrítica. Vol. 34, n. ${ }^{0} \quad 1$, 2020, p. 173-198. Disponível em: http://diacritica.ilch.uminho.pt/index.php/dia/article/view/349/137. Acesso em: 01 maio 2020.

PRENSKY, M. Fun, play and games: what makes games engaging. Digital game-based learning. New York: McGraw-Hill, 2001. p. 1-31. Disponível em: http://www.autzones.com/ din6000/textes/semaine13/Prensky(2001).pdf. Acesso em: 05 nov. 2019.

SAVI, R.; ULBRICHT, V. R. Jogos Digitais Educacionais: Benefícios e Desafios. RENOTE - Revista Novas Tecnologias na Educação, v. 6, n. 2, p. 1-10, dez. 2008. Disponível em: https://www.seer.ufrgs.br/renote/article/viewFile/14405/8310. Acesso em: 11 ago. 2019.

SOARES, M. Letramento e alfabetização: as muitas facetas. Revista Brasileira de Educação, Rio de Janeiro, n. 25, p. 5-17, abr. 2004.

Recebido em dia 02 de julho de 2020. Aprovado em dia 29 de julho de 2020. 